Status Report 2016-2019

\title{
Recent Indian Contributions from the Polar Realm
}

\author{
RAHUL MOHAN ${ }^{1, *}$, SANDIP KUMAR ROY ${ }^{2}$, THAMBAN MELOTH ${ }^{1}, \mathrm{~N}^{\text {ANILKUMAR }}{ }^{1}$, \\ K P KRISHNAN ${ }^{1}$, P SABU ${ }^{1}$, AVINASH KUMAR ${ }^{1}$, B S MAHESH ${ }^{1}$, SHRAMIK M PATIL ${ }^{1}$, \\ $S$ VENKATACHALAM ${ }^{1}$ and NARESH CHANDRA PANT ${ }^{3}$ \\ ${ }^{1}$ National Centre for Polar and Ocean Research, Goa, India \\ ${ }^{2}$ Geological Survey of India, Nagpur, India \\ ${ }^{3}$ University of Delhi, Delhi, India
}

(Received on 10 September 2019; Accepted on 29 September 2019)

\begin{abstract}
Polar science in India has gained enough impetus post the 1980's with the launching of the Indian Scientific Expedition to Antarctica on $6^{\text {th }}$ December 1981 and the establishment of the Department of Ocean Development (now the Ministry of Earth Sciences). Indian scientific endeavors in the polar realm are tripolar with emphasis on the Arctic, Antarctica (including the Southern Ocean) and the recent addition of Himalayas to the mandate (not covered in this article). The scientific endeavors of the Indian Scientific Expedition to Antarctica (ISEA) have increasingly covered a wide spectrum of fields since 1981. These include, geological investigations of exposed outcrops in the vicinity of the Indian Antarctic research bases, paleolimnological studies, satellite remote sensing related work, polar biological science, and the snow, ice and ice core studies. Indian researchers have put footprints in the Arctic (since 2007) at the Ny-Ålesund scientific village, Svalbard. India therefore has now its presence in both Arctic and Antarctica with active research bases (Arctic: Himadri; Antarctica: Maitri and Bharati; managed by the National Centre for Polar and Ocean Research based in Goa). In addition, India launches dedicated expeditions to the Southern Ocean to decipher its hydrodynamics and biogeochemistry. A brief overview of scientific achievements of Indian researchers in the various fields of research is provided in this compilation.
\end{abstract}

Keywords: Polar Science; Southern Ocean; Arctic and Antarctica

\section{Geological Studies}

In the view of twin limitation of scanty outcrops and logistic constraints in reaching rock exposures, most of the Antarctic geology has evolved either (a) near vicinity of the permanent research stations owing to better accessibility of resources; or (b) in expedition cum camping mode to cover relatively remote areas. The Indian Antarctic Expeditions started in the year 1981 with building a permanent research base (Dakshin Gangotri) firstly on Ice shelf of the Lazarev sea and then second research base (Maitri) on stable rocky outcrops of the Schirmacher Oasis. The initial thrust was preparation of baseline geological maps of the region, what started as a much localized geological mapping and interpretations of the Schirmacher Oasis later expanded into geological mapping and crustal evolution studies of a sizeable 19,000sq. $\mathrm{km}$ of the central Dronning Maud Land (cDML) region. From the year 2011, with the building of India's third research station - 'Bharati' in the Prydz bay, Indian contributions to Antarctica started with the initiation of mapping and understanding the geological complexities of this region.

Contributions towards possible extension of the East African Orogeny (EAO); Late Quaternary climatic conditions; Polar ice-sheet dynamics and to an extent sub-ice geology sums up the present pursuit of country's geoscientists. In this section, recent salient contributions to Antarctic geology are described for the three domains, namely, the central Dronning Maud Land (cDML), the Larsemann Hills, and the Wilkes Land sector.

\section{The Central Dronning Maud Land Sector (from East to West)}

Geological Survey of India (GSI) has completed 
systematic regional mapping between $3^{\circ} \mathrm{E}$ to $15^{\circ} \mathrm{E}$, covering an area approximately 19,000 sq. $\mathrm{km}$ on 1:50,000 scale. The area covered include, the mountain ranges of Wohlthat, Orvin and part of Muhlig Hoffmannfjella in the cDML of the East Antarctica. The small hillocks (nunataks) in these areas as well as in the Schirmacher Oasis on which the Indian station is located, have also been covered. Wohlthat Mountains (German: Wohlthat massiv) is a large group of associated mountain features consisting of the Gruber, the Petermann Ranges and the Humboldt Mountains, which is located immediately east of the Orvin Mountains in Fimbulheimen in the central Queen Maud Land.

Area between the Schirmacher Oasis and Humboldt Mountains is covered by a thick polar icesheet. However, there are eight nunataks of approximately $4-10 \mathrm{~km}^{2}$ in the area that stand out projected above the ice sheet. These nunataks are strategically placed to infer the sub-ice geology. These nunataks are namely Tallaksenvarden, Stenersenknatten, Baalsrudfjellet, Hauglandtoppen, Sonstebynuten, Starheimtind, Pevikhornet etc. and others such as Austree and Midtre lying north of the Petermann ranges. These nunataks have been investigated by Kaul et al. (1988), Roy et al. (2017) and others, who have described the geology and petrography of the gneisses, basic granulites and quartz-syenite rocks exposed therein.

The studies indicated that, the cDML occupied a prominent position in the processes involving formation of the mega continents like Rodinia and Gondwanaland. Geological observations made in Antarctica are being extended to conceptualizing models and processes of crust formation during two major tectonic events - Grenvillian and Pan-African those were associated with the formation of these super continents. Apparently, these important geological events in the cDML have larger intercontinental implications and can be correlated with important geological terrain in Mozambique, South Africa and Madagascar. The sustained efforts with a systematic approach in the fieldwork and resultant database will eventually help to evolve a model of best fit of landmasses in Gondwanaland. The outcome of continued regional geological mapping has enabled GSI to publish geological maps most parts of the region. These maps have been circulated to the Scientific
Committee on Antarctic Research (SCAR). Geological Survey of India has also been conducting thematic studies to evaluate metamorphism and tectonic events in Humboldt Mountains and in the area to the south of the Schirmacher Oasis.

Based on the similarities of granulites representing 660Ma-600Ma (Stern1994) to those of Schirmacher Oasis (Ravikant et al., 2004, 2007; Baba et al., 2006), the EAO has been extended to the cDML, Antarctica through Schirmacher Oasis. Rocks of the Schirmacher Oasis have shown to be late Neoproterozoic. Structurally, the NE-SW trending shear zones and mylonites in the Schirmacher Oasis show flow planes parallel to regional foliation of EAO are believed to have evolved during the late phase of $\mathrm{D}_{2} / \mathrm{M}_{2}$ to early $\mathrm{D}_{3} / \mathrm{M}_{3}$ tectonothermal event. Based on the regional settings, nature and timing of this shear zones and its association with the retrogressive amphibolite facies metamorphism, these shear zones are opined to be a part of exhumation (D'Souza et al., 2011; Pant et al., 2017).

The cDML regions expose Mesoproterozoic polydefomed, magmato-metamorphic terrain of highgrade rocks that have undergone granulite grade of metamorphism. The southern extension of EAO is believed to have acted as a suture between the East and West Gondwana blocks during Neoproterozoic (Pant et al., 2013, Pant 1991; Pant et al., 2009, 2013). Pant et al. (2013) opined that metamorphic neocrystallization began in Neoproterozoic at $\sim 640$ $650 \mathrm{Ma}$ time and continued up to $580 \mathrm{Ma}$. The $500-$ 600 Ma magmatic activity is wide spread in the cDML.

The protracted metamorphism was overprinted by a strong thermal imprint at $\sim 540 \mathrm{Ma}$ and it is correlatable with large scale charnockite and A-type granite emplacements. Extensive pan-African thermal imprint in the Whol that Mountains is represented by anorthosite $(\sim 600 \mathrm{Ma})$, charnockite and anorogenic granite. The zone of $\sim 640 \mathrm{Ma}$ granulite grademetamorphism is inferred as the remnant of suture between East and West Gondwana (Pant et al., 2013).

Dharwadkar and Shrivastava (2017) have recorded the presence of orthopyroxene within the amphibolitic enclaves in Gjelsvkfjella in the western margin of the cDML suggesting an earlier granulite grade event. Geochronological studies assign an age 
of 1170Ma to 970Ma for the migmatites/gneisses and an emplacement age of 501Ma for the Stabben gabbro and syenite.

\section{Recent Contributions from the Larsemann Hills}

Larsemann Hills in the Prydz Bay region of the East Antarctica offers a key setting for correlation between the East Antarctica and the Eastern Ghat Belt of eastern India. The study of Grenvallian ( 1000Ma) Pan-African ( $\sim 500 \mathrm{Ma})$ high grade tectonometamorphic evolutionary history in the Prydz Bay, including Larsemann Hills and its adjoining areas, like Sostrene Islands, Bolingen Islands, Brattstr and Bluffs, Rauer Islands, Vastfold Hills etc. is significant in the present-day reconstruction and correlation with India and East Antarctica.

The major rock types exposed in the Larsemann Hills area are: garnetiferous granite granodiorite gneiss; orthopyroxene bearing granite representing the metamorphosed acid igneous suite; pyroxene granulite representing the metamorphosed basic igneous suite and the metapelite representing the metamorphosed sedimentary suite. Small scale quartzo-feldspathic melts (migmatite) are also preserved at a few locations. The post tectonic igneous suite is represented by small patches of granitoids. Mapping of few Islands by GSI have been completed in this sector.

Ghosh et al. (2017), presented new U-Pb Zircon ages using Multicollector LA-ICP-MS which supports presence of a Late Neoproterozoic basin in the Larsemann Hills. They sampled and dated zircons from Bradstr and Paragneiss that were devoid of any visible metamorphic melt segregations. Zircons from all three sedimentary rocks dated show prominent concordant cluster around $550 \mathrm{Ma}$. In fact, in the bedded meta-arkosic rock of McLeod Island 550Ma is the dominant concordant cluster. This rock is interpreted to be a tuffite and signifies the age of deposition of basin. The interpretation of Grew et al. (2012) shows that, younger concordant clusters of 800Ma and 550Ma in the Tasse Tarn metaquartzite signifies new zircon growth during metamorphism is not supported by this data.

\section{The Princess Elizabeth Land (PEL) and Contiguous Areas}

The first campaign of an international collaborative project, ICECAP (International Collaborative Exploration of Central East Antarctica through Airborne geophysical Profiling), funded partially by United Kingdom Global Innovation Award was undertaken in 2015-16. This season operations were hosted by the Polar Research Institute of China (PRIC) and conducted from the Zhongshan Station with participation from USA, UK, China and India using airborne geophysical surveys for 44,000 line km of ice sounding radar, laser altimetry, gravity andmagnetic data collection. Following are some of the preliminary findings of this campaign (Sun Bo et al., 2016).

- PEL hosts an assortment of previously unidentified subglacial lakes and complex geomorphology.

- Confirms the presence and extent of a 1,100 $\mathrm{km}$-long system of canyons connecting the Lambert Rift to the Leopold and Astrid Coast.

- A subglacial lake situated within the southern section of the canyon system, likely one of thelargest known lakes in the Antarctica.

Corroborative geological field investigations are in progress.

\section{The Wilkes Land Sector}

Examination of heavy mineral fraction of the marine sediments of Integrated Ocean Drilling Program (IODP) Expedition 318 off the coast of the Wilkes Land in the East Antarctica (drill site U1359) brought out the sourcing of sediments from the Precambrian hinter land constituting the East Antarctic shield as well as from the Palaeozoic Trans Antarctic Mountains and Ross Orogen (Pant et al., 2013). The shield area is indicated to be a polymetamorphic terrain with a low-grade orogeny indicated by $\sim 800 \mathrm{Ma}$ monazite within biotite schist (Pant et al., 2016). This is the first report of signatures of a Neoproterozoic orogeny in this area and has significant bearing on the Australo-Antarctica reconstruction. Clay mineral record was employed to reconstruct the fluctuations of the East Antarctic Ice Sheet (EAIS) during MioPliocene and increased concentration of smectite suggested retreat of EAIS during 6.8Ma-6.2Ma, $5.8 \mathrm{Ma}-5.5 \mathrm{Ma}$, and $\sim 4.5 \mathrm{Ma}-2.5 \mathrm{Ma}$ possibly coincident with the formation of the Antarctic Bottom Water in the Ross sea (Verma et al., 2014). The period 
between $7 \mathrm{Ma}-9 \mathrm{Ma}$ at this depocenter marks the maximum concentration of Ice Rafted Debris (IRD) which includes basaltic rock fragments sourced from the Ferrar Large Igneous Province towards east. This is also in conformity with the ice-retreat phases inferred using clay minerals at 7.4Ma-7.3Ma and $\sim 8.5$ Ma (Verma et al., 2014). Unusual mafic rock fragments in Plio-Pleistocene marine sediments were recorded from the East Antarctica (suspected meterotite fragments) at IODP Site U1359, deposited between $c$. 3Ma and 1.2Ma (Pant et al., 2018).

\section{Paleolimnological Studies}

Antarctica plays a vital role in controlling Earth's climate. Recent records indicate that there has been unprecedented change in the Antarctica. Therefore, collecting past climatic information from ice-cores, marine sediments, and lake sediments are extremely important as the data can be utilized in the available models to plausibly model the future climate for the region. There are very few researchers who have focused on Antarctic paleolimnology which is reconstructed from ice-free regions of the East Antarctic viz. Schirmacher Oasis, Larsemann Hills and Vestfold Hills. The paleolimnologists have employed multi-proxy approach through environmental magnetism, sedimentology, sedimentary geochemistry, biogenic silica, diatoms, and major and minor trace elements to reconstruct past Antarctic climate history (see Table 1). Majority of the earlier work from Indian researchers was able to resolve historical climate up to Holocene. In the past one decade, paleolimnologists were able to retrieve longer sediment cores and resolve climate data beyond the Last Glacial Maximimum (up to $43 \mathrm{kyr}$ ). Also, high resolution records have been published from Larasemann Hills, as compared to the low-resolution records of Schirmacher Oasis. Warrier et al. (2017), in a review paper published in PINSA has discussed in detail the initial works on lake biogeochemistry by the Indian researchers along with the works on lake surface sediments. Early historical records from the Schirmacher Oasis (Phartiyal et al., 2011; Phartiyal, 2014) are limited to the Holocene. The paleolimnological group of National Centre for Polar and Ocean Research has made significant contributions to the past-climate reconstruction from the Antarctic coastal regions where marine sediments and ice-core data is limited due to coastal dynamics.
Hence, the lake records form one of the most important and crucial archives along the Antarctic continental margin which respond rapidly to changes in climate and integrating the information about climatic changes in the sediments.

The first long-term record spanning glacialinterglacial stage was published based on environmental magnetism (Warrier et al., 2014) for Sandy Lake located in the Schirmacher Oasis for past $42 \mathrm{kyr}$. Further studies were carried out in the Schirmacher Oasis utilizing other proxies such as, size and surface textural observations of quartz grains (Mahesh et al., 2015; Warrier et al., 2015; Choudhary et al., 2018) to understand the sediment transport processes and their depositional environment. A recent study from the Schirmacher Oasis (Choudhary et al., 2018) discuss about the type of weathering, hydraulic sorting occur during transport to the lake basin, topographic setting and climatic conditions which regulate trace elements abundance and distribution in sediments. Another study based on long-term trends (up to $22 \mathrm{kyr}$ ) in the grain size distribution and biogenic silica variation suggest that, the possible fluctuation of the Antarctic ice-sheet superimposed on global climatic fluctuations due to solar activity in the Schirmacher Oasis. A solitary record from the Vestfold Hills lake documented the presence of inverted sequences with older sediments rich in marine microfossils and increased abundance of broken diatoms, which was inferred as a result of paleostorm (Raza et al., 2018). Previous research has revealed the importance of sedimentary organic matter to understand the productivity pattern, depositional environment and source of organic matter in the lake. The sedimentary organic matter based stable isotope geochemistry has revealed crucial information about the past lake environment and its response to the Antarctic climate (Mahesh et al., 2015; 2017; 2018; 2019).

\section{ICE Core Studies}

Study of ice core proxy records provide one of the most direct and accurate method to study the Antarctic climate change beyond the instrumental limits. The Indian ice core initiatives focusing on the highresolution proxy based studies during the past few centuries have enhanced the understanding of the Antarctic climate variability and the various factors 
involved. The proxy environmental parameters used include temporal variability of stable isotopes, trace metal chemistry, ionic composition, dust particulates, and microbial components that are indicators of environmental change in the coastal Antarctica. The shallow (up to $100 \mathrm{~m}$ depth) ice core proxy based reconstruction by the Indian scientists revealed significant changes in the Southern Hemispheric climate during the past several hundreds of years (Laluraj et al., 2014; Thamban et al., 2013, 2016; PAGES 2k Consortium, 2013; Rahaman et al., 2016 and 2019). Salient findings of the ice cores studies during the past five years are discussed below.

The nitrate $\left(\mathrm{NO}_{3}^{-}\right)$profile in an ice core revealed a close relationship with the Antarctic ${ }^{10} \mathrm{Be}$ record (solar proxy) and supported significant changes in the temperature during periods of solar activity as well a warming trend of $2.7^{\circ} \mathrm{C}$ for the past 470 years, with an enhanced warming during the last several decades (Thamban et al., 2013). The ice core based temperature reconstructions during the past five centuries also revealed substantial warming by $0.6^{\circ} \mathrm{C}$ $1^{\circ} \mathrm{C}$ per century, with greatly enhanced warming during the last few decades $\left(\sim 0.4^{\circ} \mathrm{C}\right.$ per decade) (Thamban et al., 2013). The dust record of IND-25/ B5 ice core showed that dust deposition in the East Antarctica followed the Southern Hemispheric climate change and doubled during the $20^{\text {th }}$ century (Laluraj et al., 2014). Strong positive correlation observed between ice core dust flux and the Southern Annular Mode (SAM) revealed that the positive values of the SAM index are likely to be responsible for the recent increase in dust deposition over East Antarctica, through strengthening of westerly winds. Interestingly, the timing and amplitude of the insoluble dust flux matched remarkably well with the trace metal fluxes of $\mathrm{Ba}, \mathrm{Cr}, \mathrm{Cu}$, and $\mathrm{Zn}$, confirming that dust was the main carrier of airborne geochemical tracers to East Antarctica in the recent past (Laluraj et al., 2014). The observed doubling of dust and associated trace metal deposition in the East Antarctica have wideranging implications for understanding the factors driving the inter-continental transportation of impurities and their environmental impact on the Antarctica.

Proxy records of sea ice [sea-salt sodium (ss$\mathrm{Na}^{+}$) and methane sulfonic acid (MSA)] and moisture [deuterium excess (d-excess)] variability of IND-25/ B5 ice core also revealed the history of moisture transport and sea ice condition during the last century (Rahaman et al., 2016). This study suggested that moisture source and sea ice variability in annualdecadal scale in Antarctica seems to be largely influenced by SAM and its teleconnection to ENSO. The Antarctic surface air temperature (SAT) reconstructed approximately for the past five centuries ( $\sim 1533$ to $1993 \mathrm{CE}$ ) based on multiple oxygen isotope $\left(\delta^{18} \mathrm{O}\right)$ records of ice cores from East and West Antarctica show dominant oscillations in ENSO and Pacific Decadal Oscillation (PDO) frequency (Rahaman et al., 2019). Further, variance of the East Antarctica temperature record shows significant increasing trend at ENSO band and decreasing trend at PDO band since the post-industrial era $(\sim 1850 \mathrm{CE})$. This study suggested that the ENSO activity and its influence on Antarctic temperature are increasing in response of continuing greenhouse warming since the industrial era.

The Indian ice core studies have also contributed to the PAGES $2 \mathrm{k}$ synthesis of past 2000 years of truly global temperature reconstruction across the globe (PAGES 2k Consortium, 2013). Integrating the proxy temperature data using various proxy records across seven continental-scale regions, this global study revealed an overall cooling trend across nearly all continents during the last two thousand years. This cooling trend was reversed by distinct warming, beginning in some regions at the end of the $19^{\text {th }}$ century.

\section{Satellite Remote Sensing Based Studies}

To understand the mechanism of sea-ice expansion in the Indian Ocean sector of Antarctica (IOA), satellite derived analysis of sea-ice extent, during 1979 to 2015 , in the IOA revealed expansion of $2.4 \pm 1.2 \%$ decade $^{-1}$. The study resulted in strengthening of westerly wind during the austral summer facilitated northward advection of a cool and fresh layer (Jena et al., 2018). NCPOR initiated a series of geospatial activities to an accurate DEMs and land cover maps of the cryospheric regions such as, satellite-based DEM for monitoring Antarctic topography with a special focus on glaciers (Jawak and Luis, 2016); synergistic use of imaging SAR, GLAS/ICESat and ground survey (GPS) data to produce an accurate DEM of the Schirmarcher Oasis and the Larsemann Hills (Jawak and Luis, 2012). During the $35^{\text {th }}$ Indian 
Scientific Expedition to Antarctica, inter-annual variations in the backscatter response of fast ice using ground penetrating radar (GPR) and backscattering coefficient from scatterometer in the Larsemann Hills, East Antarctica, studies show volumetric contribution from sheet ice and domination of snow metamorphism towards increase in backscatter over fast ice (Bothale et al., 2018). Jayaprasad et al. (2016) studied two of the Indian Satellites namely Radar Imaging Satellite1 (RISAT-1) and Resource SAT-2 (RS-2) for monitoring and mapping of the Antarctic terrain. It is extended for other applications such as change detection studies, safer ship navigation and extreme events of the Antarctica.

\section{Polar Biological Research}

The Polar Regions always received a significant attention for biological research due to their pristine nature, where it is comparatively easy to predict, measure and to develop model systems for understanding the origin microbial life forms and their role in the functioning of marine as well as terrestrial ecosystems (Venkatachalam et al., 2019). The geographical surface area of polar region is about 10.9 million sq. mi. of the earth biosphere, with about 46 countries actively undertaking polar biology based research activities every year. Based on the scientific findings and applications from the Antarctic research activities, Indian Arctic programme was initiated in the year 2008 and scientific experiments were conducted. Significant contributions were accomplished in the field of natural sciences within the areas of microbiology and molecular biology by researchers across Indian institutes and universities. Here, in this subsection, we are summarizing significant research activities undertaken by Indian researchers in the polar regions within the domain of biological research for past ten years.

\section{Microbial Diversity Based Research for Bioprospecting Applications from Polar Environments}

Microorganisms are the primary drivers of any ecosystem, which play a critical role in keeping the ecosystem in a healthy state through nutrient recycling. It needs to be emphasized that microbes living in the harsh climatic conditions, also known as psychrophiles (grow from subzero to $30^{\circ} \mathrm{C}$ ) are found to have distinct applications on healthcare sectors, metabolites and enzyme industries (Cavicchioli 2015). Till now, various microbial diversity-based studies have been led by Indian researchers on different habitats of the polar regions, including soil, cyanobacterial mats, water, sub-glacial outflows, fjord systems, oceanographic frontal systems, freshwater lakes, sediments and ice cores during past ten years. Researchers from the Centre for Cellular and Molecular Biology (CCMB), extensively worked in the various habitats of polar environments and have isolated more than 30 novel microbial species belonging to the members of genera Thalassospira, Iodobacter, Arcticibacter, Winogradskyella, Cyclobacterium, Oceanisphaera, Arthrobacter, Leifsonia, Exiguobacterium, Marinomonas sp., with few draft genomes by using next generation sequencing based technology from the various habitats of polar region (Shivaji, 2017). Significant key findings have also been published on marine environments in the past few years especially in the polar frontal regions. It was shown that, distinct microbial communities are known to assist in enhanced primary productivity of the surrounding regions of sub Antarctic islands (Sivasankar et al., 2018; Venkatachalam et al., 2019). Biological diversity of the marine ecosystems in the Arctic regions, especially, fjord ecosystems are extensively studied by researchers from the National Centre for Polar and Ocean Research, which is known for its complexity due to heavy discharge of glacial meltwater into the fjord system. It has also been demonstrated that increasing incidence of warm water associated microbial communities were observed in the fjord systems, due to the intrusion of Atlantic water bodies (Sinha et al., 2017). Bacterial communities were further explored for their role in biogeochemical processes (Carbon, Nitrogen and Phosphorus cycling). Further, significant number of culture based studies were also being done in the past, with an aim to isolate industrially important microbial strains for potential enzyme producers including amylases, cellulases, pectinases, proteases, lipases and $\beta$ galactosidases (Hatha et al., 2013; Neethu et al., 2012; Salam et al., 2017; Srinivas et al., 2009).

\section{Anthropogenic Activity Associated Biological Research in Svalbard, Arctic}

Thawing permafrost, rapid melting of glaciers, accelerated heavy discharge of glacier freshwater, 
which also carries significant amount of sediments from coal mining areas into different fjord systems, has significant impact on the native microbial flora. Recent studies have shown the presence of high mercury content and associated mercury tolerant bacteria (Bineesh et al., 2018) in the fjord sediments. Furthermore, fjords and associated adjacent tundra ecosystems are also being investigated for the presence of health indicator bacteria, whereas, it is being hypothesized that migratory birds such as Arctic terns, Barnacle goose are assisting in the widespread distribution of the mesophilic, antibiotic resistance microbes in the Arctic environments (Hatha et al., 2015). Further microcosm studies on how these mesophilic and other pathogenic bacteria are adapting to the cold climatic conditions will be of great importance in this area of research.

\section{Future Perspectives}

Laboratory culture based microbiological investigations have been a gold standard in the polar research with respect to the isolation of novel bacteria species and further exploitation of these strains for bioprospecting potentials. In the era of drastic climate variability, indigenous microorganisms in the polar ecosystems are constantly under selection pressure, where many such ecosystems are slowly shifting towards more temperate conditions and species within these systems are changing in time and space. To understand these complex processes, the current advancement in genome based high-throughput sequencing technologies will be of great help to understand and monitor the changes in the polar ecosystems in order to harmonize and negate the impact of anthropogenic activities. During the last few decades, significant progresses were achieved by the studies carried out by Indian researchers in the polar regions. Further, exploring the unexplored regions in the polar environments will provide more unique opportunity to study about structure and functioning of different ecosystems, with an aim to get leads for novel therapeutic agents and health supplements. With this aspect in the forefront, the National Centre for Polar and Ocean Research is spearheading many new expeditions to the coastal areas of the Northern Svalbard and associated Arctic open ocean to venture into the unexplored territory of the Arctic regions.

\section{Arctic Palaeoceanographic Studies}

Studies of marine sediment cores provide the sedimentary, geochemical and biological evidence of past changes in the Earth system. The sediment cores provide robust reconstructions of large oceanographic regions and provide insights to climatic change beyond the instrumental data available. The palaeoceanographic data from the sediment cores derived from many proxies found in deep sea sediments including microfossil composition, isotopic composition of microfossils and lithology etc. The Indian palaeoceanographic research ventures in the Arctic, has improved our understanding of its climate variability for the past few centuries and scaling back up to 14,500 years BP, covering the entire Holocene and before. The research projects include both Ministry of Earth Science (MoES) funded in-house projects and international collaborative projects. The important findings and publications within the last few years are discussed below.

The diatom microfossil-based quantitative SST reconstructions from Iceland basin showed that the cold interval at 4-2ka BP may have resulted from a strengthened East Greenland Current and/or melting of Greenland ice sheet in response to a negative North Atlantic Oscillation. It highlights the influence of atmospheric circulation changes that likely cause pronounced variations in the latitudinal heat exchange which may have consequences for deep water formation and global ocean circulation (Orme et al., 2018). The biogeographic distributional studies of polycystic radiolarians from the North Atlantic revealed the distribution and interaction of water masses from Polar to North Atlantic was clearly reflected in assemblages retrieved from deep sea sediments; three from the North Atlantic and two from the Nordic seas (Matul and Mohan, 2017). The diatom and coccolithophore microfossil-based temperature reconstructions from the eastern Fram Strait reveal that in the last 2000 years, the Roman Warm Period (upto $456 \mathrm{CE}$ ) and Recent Warm period (1850 CEpresent) to be the warmest intervals throughout this time period (Matul et al., 2018). The multi proxy (sedimentary organic matter, ${ }^{13} \mathrm{C}$ and ${ }^{15} \mathrm{~N}$ isotope ratios and microfossil abundance) study from Kongsfjorden, Svalbard revealed warming driven melt-dynamics history of the fjord for the past 200 years. The proxy data shows decreasing trends in 
productivity, which was controlled by the melt dynamics throughout the last two centuries (Kumar et al., 2018). The microfossil (Foraminifera) and isotope proxy-based study along with paleotemperature estimates from Reykjanes Ridge, document that after the warm Bølling-Allerød (BA), the middle Younger Dryas (YD) ca. 12.5ka-12.2ka was the next significant step towards the Holocene warming. Also, warming in the region during Termination I occurred on subsurface regions earlier than the sea surface; also proposes further studies into the question (Matul et al., 2018).

The MoES funded in-house projects along with the collaborations by Norwegian research council (OCTEL) and Russian Science Federation reveals the climatic variability across the Arctic from $14.2 \mathrm{ka}$ BP till the present day. The multi-proxy studies, from marine sediment cores obtained from $40^{\circ} \mathrm{N}$ to $79^{\circ} \mathrm{N}$ reveals various climatic oscillations and oceanographic changes within the time period studied but with significant warming in the Arctic post $19^{\text {th }}$ century, opposed to the cooling trend which was observed during the late Holocene.

\section{Southern Ocean Processes and Ecosystem Responses}

The Southern Ocean (SO) is a unique region which tends to have a global scientific relevance in terms of its role in climate change, its distinct physical, chemical properties and related biological processes. In the light of above perspective, the SO in general and the Indian sector of the SO (ISSO) in particular, is still an understudied region. In ISSO, the Subtropical and Polar Fronts confluence and split again, but the exploration to understand the mechanisms of this variability in these regions are very sparse (Belkin and Gordon, 1996). The seasonality and extent of seaice formation are shown to influence the oceanographic as well as the biogeochemical processes across various fronts in the SO. It was reported that Antarctic ice sheet mass loss has been linked to an increase in oceanic heat supply that enhances the basal melt and thinning of the Antarctic ice shelves (Herraiz-Borreguero et al., 2015). Also, accelerated glacier discharge into the SO due to the collapse of ice shelves could be one of the major sources contributing to sea level rise (Scambos et al., 2004; Shepherd et al., 2010). Although warm water near the coast is thought to be the main factor causing the ice to melt, the process by which this water ends up near the cold continent is not well understood. In order to understand the processes those are involved in modulating the climate variability in a regional as well as global scale and its implications on the living resources, biogeochemical cycles and sea level rise, Indian SO research program was initiated by MoES in 2004 with the National Centre for Polar and Ocean Research as a national nodal agency. Till date, 10 expeditions have been carried out in the region between $40^{\circ} \mathrm{S}$ and $69^{\circ} \mathrm{S}$ and $40^{\circ} \mathrm{E}$ and $80^{\circ} \mathrm{E}$ (Fig. 1). More than 20 National/International organizations/ Universities participated in these multidisciplinary and multi-institutional expeditions. However, the information gathered from these expeditions are not sufficient to establish the influence of the SO on global climate and also at what extent the SO processes respond to or drive the tropical climate variability. This underscores the need for sustained observations from the SO to understand the physical and biogeochemical processes responsible for climate variability. Therefore, in future, detailed investigations will be carried out in the Tropical Indian Ocean (TIO) as well as ISSO to understand the teleconnection between high and low latitude biogeochemistry and climatic changes.

\section{Scientific Outcomes}

Due to the influence of Southwest Indian ridge and Weddell gyre, the eastward flowing Antarctic Circumpolar Current (ACC) is meandering towards south in the ISSO, which perhaps brings warm water to the coastal Antarctica and causes glacier/sea-ice melting and further the freshening of bottom watermasses (Anilkumar et al., 2014, 2015). The Subtropical Front (STF) is the most dynamic region in the $\mathrm{SO}$, where eddies are more predominant when Agulhas retroflection confluence with the STF. Eddies present in the STF transported Subtropical Surface Water (STSW) southward by means of the enhanced meridional velocities along the peripheries of eddies (Chacko et al., 2014), and the presence of cyclonic eddy significantly transported cold and fresh Antarctic Intermediate water (AAIW) from deeper depths $(>1000 \mathrm{~m})$ to near surface. Anti-cyclonic eddies are transporting high saline subtropical surface waters to south from their source region (Sabu et al., 2015). The subtropical front being a highly mesoscale 


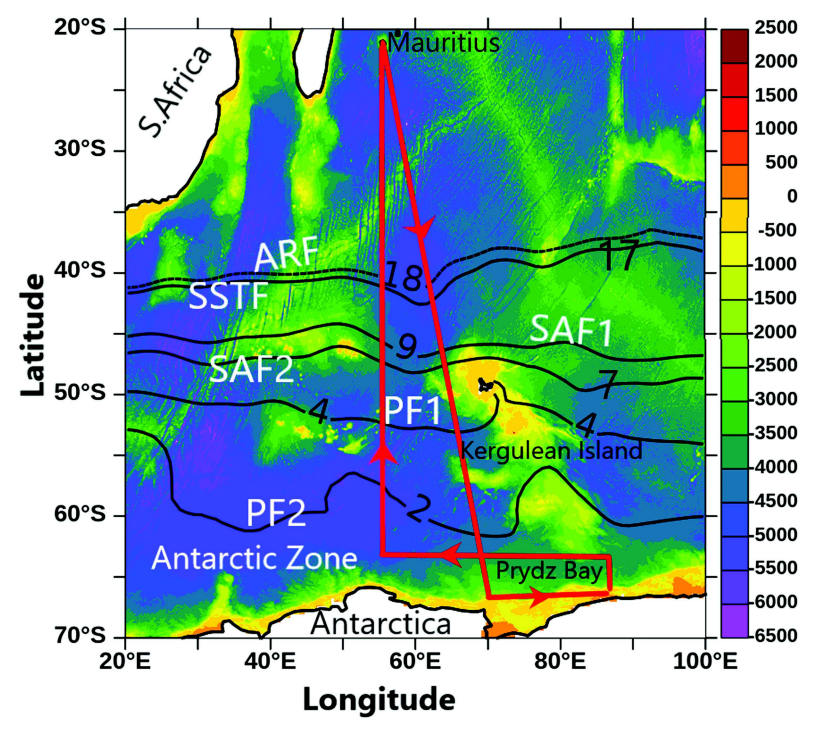

Fig. 1: ISSO study region. Position of the fronts is marked using WOA climatology data. Background color represents the bathymetry of the study region from ETOPO data

turbulent region, the primary supply of nutrients is attributed to advection (vertical or zonal) rather than vertical mixing (George et al., 2018). The ocean sectors north and south of $16^{\circ} \mathrm{S}$ are dominated by continental aerosol and maritime aerosol with the sea salt and non sea salt components, respectively (Menon et al., 2015). High degree of freshening of Antarctic Bottom Water (AABW) was observed from 2006 to 2010 in the ISSO, which is attributed to both the Weddell Sea and Cape Darnley Polynya origin (Anilkumar et al., 2015). Freshwater layer thickness relative to the winter water in 2011 was more compared to that during 2010. This was due to the increased amount of sea ice present in the 2010 winter, its subsequent melting and advection of melt water from south and west of the study region. The increase in Chlorophyll $a(\mathrm{Chl} a)$ concentration $\left(\sim 0.38 \mathrm{mg} \mathrm{m}^{-3}\right)$ observed south of the Polar Front1 in 2011 both in insitu observation and satellite data is attributed to the influence of this melt water (Anilkumar et al., 2015). Furthermore, the low saline waters formed by melting of glacial ice and snow could be the predominant factor for the high Chla $\left(>3 \mathrm{mg} \mathrm{m}^{-3}\right)$ resulting in high mesozooplankton biomass and abundance along the coastal region $\left(65^{\circ} 40^{\circ} \mathrm{S} ; 57^{\circ} 30^{\prime} \mathrm{E}\right)$ (Anilkumar et al., 2014).The enhanced Chla observed in the study region $\left(60^{\circ} \mathrm{S} ; 47^{\circ} \mathrm{E}\right)$, was attributed to the phytoplankton bloom, likely resulted from the influx of nutrient-laden freshwater derived from melting sea ice (Sabu et al., 2014). A strong relationship between wind speed and concentration of atmospheric $\mathrm{CO}_{2}$ has been encountered, and at south of $50^{\circ} \mathrm{S}$ the mixing of ventilated $\mathrm{CO}_{2}$ was observed (Prasanna et al., 2015). Variations of $\delta^{13} \mathrm{C}$ and $\delta^{15} \mathrm{~N}$ in Particulate Organic Matter (POM) in the surface waters exhibited depletion in $\delta^{13} \mathrm{C}$ and a wide range of $\delta^{15} \mathrm{~N}$ of POM in the TIO compared to ISSO and it was largely controlled by biological community and biological activity (Soares et al., 2015). Increase in the $\delta^{13} \mathrm{C}$ (DIC) value of the surface water with latitude is observed between $35^{\circ} \mathrm{S}$ and $\sim 60^{\circ} \mathrm{S}$, with a peak at $\sim 42^{\circ} \mathrm{S}$. This can be caused by increased organic matter production and associated removal (Prasanna et al., 2016). Stable isotope ratios of water vapor, rainwater and seawater samples from the TIO and the ISSO showed features characteristic of evaporation and precipitation zones (Rahul et al., 2018). Variation in phytoplankton community structure was observed at six hours intervals and that was actively governed by top-down control at juncture of the Agulhas Retroflection Front (ARF) and the STF (Naik et al., 2015). Tripathy et al. (2014) reported that Chla concentration was very high in the coastal waters of Antarctica; however, the corresponding primary productivity $(\mathrm{PP})$ values were not very high compared to the offshore stations. High Chl $a$ and primary productivity observed at the PF was attributed to the dominance of diatoms. Owing to their higher sinking rate, the diatoms with sequestered $\mathrm{CO}_{2}$, would generate substantial export production/flux, thereby making the PF region as a sink for atmospheric $\mathrm{CO}_{2}$ (Tripathy et al., 2015). The changes in environmental settings can influence biological community succession by providing windows for opportunistic groups of phytoplankton, thereby influencing the carbon sequestration efficiency of this ecosystem (Naik et al., 2015; Mishra et al., 2015, 2017). Discrepancy in the ecological efficiency and the plankton community structure suggest a multivorous food web and a conventional food web at the subtropical and polar fronts respectively (Pillai et al., 2018). A strong contrast in terms of zooplankton population structure and biovolume was observed between the Subtropical and Polar Fronts (Venkataremana et al., 2019).

\section{Southern Ocean Paleoceanography Contribution}

The SO is considered as a crucial region for global 
climate and ocean biogeochemical cycling. Indeed, the SO forms a link between the Atlantic, Pacific and the Indian Oceans and modulates the global circulation which holds a key to the future climate. Considering the importance of ocean, it is important to fully understand it and the microfossil forms this gateway for revealing the past of oceans. These are the remnants of microscopic flora and fauna which thrive in different conditions of the ocean. This includes siliceous organisms like diatoms, radiolarians, silicoflagellates or the calcium bearing organisms like foraminifera and coccoliths. The Indian researchers have contributed in all the fields of microfossils through surface sediments, water samples and sediment cores in understanding the SO paleoceanography.

A significant step towards understanding the role of coccolithophore as a proxy for environmental variation has been taken up. In view of this, a study by Patil et al., 2017 focused on understanding the biogeographic distribution of extant coccolithophores, which provided a vital knowledge on vertical and latitudinal distribution and community composition quantitatively along N-S transect in the Indian sector of the SO. Their study also reported the morphological variation of Emiliania huxleyi in the SO using scanning electron micrographs depending upon different hydrographic conditions (Patil et al., 2014a). Occurrence of silicifying haptophytes in marine waters was largely neglected and their role in marine biogeochemical cycle was not taken into consideration. Two silicifying haptophytes (Petasaria heterolepis and Prymnesium neolepis documented from Southern Indian Ocean and ecology, biogeography and mineral composition was studied. The Energy Dispersive Spectrometric studies showed presence of calcium in the silicifying test (Patil et al., 2014b, 2015). In addition, mechanisms behind formation of xenospheres (combination spheres) were suggested as a controlled strategy to hydomechanical/ biochemical cues to sense coccoliths and incorporate into coccosphere (Patil et al., 2016).

Using isotopic compositions $\left(\delta^{13} \mathrm{C}\right.$ and $\left.\delta^{18} \mathrm{O}\right)$ of planktonic foraminifera Prasanna et al., 2016 established a linkage between geographical position and depth range of planktonic species Globigerina bulloides. The major finding of this study was the calcification depth of G. bulloides which according to the researchers is restricted to a depth of $\sim 75 \mathrm{~m}$ -
$200 \mathrm{~m}$ till $40^{\circ} \mathrm{S}$ latitude. They demonstrated the validation of the isotopic composition of G. bulloides as a paleoclimate proxy.

A study based on silicoflagellate records over the last 48kyr have been used to examine past changes in the polar frontal variability in the SO (Shetye et al., 2014). They observed a strong northward and southward shift of the Polar Front during the LGM and $43 \mathrm{kyr}-45 \mathrm{kyr}$ respectively. The Indian research is trying best to match up with the recent progresses in science has now moved one step forward and been successful in reconstructing and quantifying the northward migration of the SO fronts through past Sea Surface Temperature (SST) and Sea Ice variability. The paleoclimatic records going back till last $95 \mathrm{kyr}$ have been reconstructed using diatoms. A study by Nair et al. (2019) documented the interaction of the SO with Agulhas leakage and Asian summer monsoon. The diatom size and the abundances are being used to comment on the paleoproductivity. Their study reports the response of diatom size ( $F$. kerguelensis and $T$. lentiginosa) to the glacial interglacial variation, wherein the diatoms shows larger valve size during the Last Glacial Period. According to them the reason is possibly related to greater iron availability through wider sea-ice coverage and higher aeolian dust input. Similar studies have also been reported by Nair et al. (2015), Shukla et al. (2016), Shukla and Crosta, (2017), and Shukla and Romero (2018).

Although many studies are being carried to understand the SO paleoceanography but it still remains understudied from the perspective of longer time scale and quantitative reconstructions using microfossils. Hence, there is a need to fill this knowledge gaps as microorganisms are the first one to respond to the changes in environmental conditions.

\section{Some Salient Achievements for Past 15 Years from the Indian Expedition to ISSO}

So far, 10 expeditions were launched from 2004 to 2018 with National-International collaborations and multi-disciplinary data were generated; Nearly 90 papers were published in the International and National journals; Nearly 85 papers were presented in International /National conferences; Eight Ph.D degrees were awarded based on the data collected from the SO expeditions. Special issues: Current 
Science Nov, 2010 and Deep Sea Research II Aug, 2015 were published and special issue of Deep Sea Research II-2019 is in progress.

The SO accounts for half of the uptake of anthropogenic $\mathrm{CO}_{2}$, nutrient supply fertilize 3/4 biological production north of $30^{\circ} \mathrm{S}$ and the excess heat transferred from atmosphere. Further, the Indian Ocean is land-locked in the north and behaves differently in circulation which leads to a much faster climate change.

Considering this, the imperative queries to be addressed are.

a. How does the atmospheric and oceanic dynamics in the SO affect the tropical weather and climate?

b. How the physical processes and atmospheric

\section{References}

Anilkumar N, Chacko R, Sabu P and George J V (2015) Freshening of Antarctic Bottom Water in the Indian Ocean sector of Southern Ocean Deep Sea Research Part II: Topical Studies in Oceanography 118 162-169

Anilkumar N, Chacko R, Sabu P, Honey Pillai H U K, George J V and Achuthankutty C T (2014) Biological response to physical processes in the Indian Ocean sector of the Southern Ocean: A case study in the coastal and oceanic waters Environmental Monitoring Assessment DOI 10.1007.s10661-014-3990-4

Baba S, Owada M, Grew E S and Shiraishi K (2006) Sapphirine - Orthopyroxene - Garnet Granulite from Schirmacher Hills, Central droning Maud Land. In: Fütterer D K, Damaske D, Kleinschmidt G, Miller H and Tessensohn F (eds) Antarctica. Springer, Berlin, Heidelberg, 37-44

Belkin I M and Gordon A L (1996) Southern Ocean fronts from the Greenwich meridian to Tasmania Jour of Geophysical Research 101 3675-3696

Bineesh B M, Shini S, Krishnan K P and Mohan M (2018) Mercury tolerance and biosorption in bacteria isolated from Ny Ålesund, Svalbard, Arctic Journal of Basic Microbiology 58 286-295

Bothale R, Anoop S, Manne G and M Sherief (2018) Response of Fast Ice to Ground Penetrating Radar and Backscattering Coefficient from Scatterometer in Larsemann Hills, East Antarctica Current Science 59 115-552 aerosols and other trace gases are modulated by Biological pump/Biogeochemistry and vice versa?

\section{Acknowledgement}

The authors have compiled the work being carried out by the Indian community in the polar regions. However, there are many areas and work which has not been presented here owing to the scope of this review paper. We would like to place on record our grateful thanks to the Secretary, Ministry of Earth Sciences for continued support to the Polar programme and Dr. M Ravichandran, Director, National Centre for Polar and Ocean Research, Goa for the support and encouragement. The authors would like to place on record thanks to the Editors for inviting us to submit this review. This is NCPOR Contribution No P-2/2019-20.

Cavicchioli R (2015) Microbial ecology of Antarctic aquatic systems Nature Reviews Microbiology 13691

Chacko R, Murukesh N, George J V and Anilkumar N (2014) Observational evidence of the southward transport of water masses in the Indian Sector of the Southern Ocean Current Science 107 1573-1581

Choudhary S, Tiwari A K, Nayak G N and Bejugam P (2018) Sedimentological and geochemical investigations to understand sources of sediments and processes of recent past in Schirmacher Oasis, East Antarctica Polar Science 15 87-98

D’Souza M J, Roy S K, Swain A K and Dharwadkar A (2011) Detailed study of Schirmacher mylonites to determine formation time and stress, strain, temperature involved in their formation as an implication to exhumation history Report of the Geological Survey of India, (unpublished)

Dharwadkar A, Shrivastava P K and Shrivastava H B (2017) Tectonometamorphic Evolution of Jutulsessen, Gjelsvikfjella, cDML, East Antarctica Journal of the Geological Society of India 92 265-280

George J V, Anilkumar N, Nuncio M, Soares M A and Naik R K (2018) Upper layer diapycnal mixing and nutrient flux in the subtropical frontal region of the Indian sector of the Southern Ocean Journal of Marine Systems 187 197-205

Ghosh J G, Roy S K, Sadiq M and Kato A (2017) Relationship between Orthogneiss and Paragneiss of the rocks of Larsemann Hills, Unpublished GSI report 
Grew E S, Carson C J, Christy A G, Maas R, Yaxley G M, Boger S D and Fanning C M (2012) New constraints from U-Pb, $\mathrm{Lu}-\mathrm{Hf}$ and $\mathrm{Sm}-\mathrm{Nd}$ isotopic data on the timing of sedimentation and felsic magmatism in the Larsemann Hills, Prydz Bay, East Antarctica. Precambrian Research 206$20787-108$

Hatha A, Rahiman M K, Krishnan K, Saramma A, Saritha G and Deepu L (2013) Characterisation and bioprospecting of cold adapted yeast from water samples of Kongsfjord, Norwegian Arctic Indian Journal of Marine Sciences 42 114

Hatha A M, Neethu C S, Nikhil S M, Rahiman K M, Krishnan K P and Saramma A V (2015) Relatively high antibiotic resistance among heterotrophic bacteria from arctic fjord sediments than water-evidence towards better selection pressure in the fjord sediments Polar Science 9 382-388

Herraiz-Borreguero L, Coleman R, Alison I, Rintoul S R, Caven $M$ and Williams G D (2015) Circulation of modified Circumpolar Deep Water and basal melt beneath the Amery Ice Shelf, East Antarctica Journal Geophysical Research Oceans 120 3098-3112

Jawak S D and Luis A J (2016) Generation of a Precise DEM by Interactive Synthesis of Multi-Temporal Elevation Datasets: A Case Study of Schirmacher Oasis, East Antarctica in Proceedings of SPIE 9877

Jawak S D and Luis A J (2012) Synergistic Use of Multitemporal RAMP, ICES at and GPS to Construct an Accurate DEM of the Larsemann Hills Region, Antarctica Advances in Space Research 50 457-70

Jayaprasad P, Mehra R, Chawla S D, Rajak R and Oza S R (2016) Role of Indian Remote Sensing Imaging Satellites for the Antarctic Monitoring and Mapping: A Case Study around Indian Antarctic Research Stations in Proceedings of SPIE 9877

Jena B, Avinash K, M Ravichandran and Kern S (2018) Mechanism of Sea-Ice Expansion in the Indian Ocean Sector of Antarctica: Insights from Satellite Observation and Model Reanalysis PLOS ONE 13 e0203222

Kaul M K, Mukerji S, Singh R K, Srivastava D and Jayaram S (1988) Geological set-up of a part of Central Queen Maud Land, East Antarctica. Fifth Indian Expedition to Antarctica Scientific report, 1988 Department of Ocean Development, Technical Publication No. 5 57-97

Kumar V, Tiwari M and Rengarajan R (2018) Warming in the Arctic Captured by productivity variability at an Arctic Fjord over the past two centuries PLOS ONE 13 e0201456

Laluraj C M, Thamban M and Satheesan K (2014) Dust and associated geochemical fluxes in a firn core from coastal
East Antarctica and its linkages with Southern Hemisphere climate variability over the last 50 years Atmospheric environment 90 23-32

Mahesh B S, Nair A, Warrier A K, Avadhani A, Mohan R and Tiwari M(2018) Palaeolimnological records of regime shifts from marine-to-lacustrine system in a coastal Antarctic lake in response to post-glacial isostatic uplift Current Science Special Section: Asian Forum for Polar Sciences 115 1679-1683

Mahesh B S, Warrier A K, Mohan R and Tiwari M (2019) Impact of Antarctic climate during the Late Quaternary: Records from Zub Lake sedimentary archives from Schirmacher Hills, East Antarctica Palaeogeography, Palaeoclimatology, Palaeoecology 514 398-406

Mahesh B S, Warrier A K, Mohan R, Tiwari M, Babu A, Chandran A, Asthana R and Ravindra R (2015) Response of Long Lake sediments to Antarctic climate: A perspective gained from sedimentary organic geochemistry and particle size analysis Polar Science 9 359-367

Mahesh B S, Warrier A K, Mohan R, Tiwari M, Roy R, Asthana R and Ravindra R (2017) Response of Sandy Lake in Schirmacher Oasis, East Antarctica to the glacial-interglacial climate shift Journal of Paleolimnology 58 275-289

Matul A, Barash M S, Behera P and Tiwari M (2018) Paleoenvironment Variability during Termination I at the Reykjanes Ridge, North Atlantic Geosciences 8375

Matul A and Mohan R (2017) Distribution of Polycystine Radiolarians in Bottom Surface Sediments and Its Relation to Summer Sea Temperature in the High-Latitude North Atlantic Frontiers in Marine Science 4330

Matul A, Spielhagen R F, Kazarina G, Krugilkova S, Dmitrenko O and Mohan R (2018) Warm-water events in the eastern Fram Strait during the last 2000 years as revealed by different microfossil groups Polar Research 37 1-17

Menon H B, Hulswar S, Anilkumar N, Achuthankutty C T, Moorthy K K and Babu S (2015) Spatial heterogeneity in spectral variability of aerosol optial depth and its implications to aerosol radiative forcing in the Tropical Indian Ocean and in the Indian Ocean Sector of Southern Ocean Deep Sea Research Part II: Topical Studies in Oceanography 118 142-151

Mishra R K, Jena B, Anilkumar N P, Naik R K, Bhaskar P V and Soares M (2017) Variability of chlorophyll-a and diatoms in the frontal ecosystem of Indian Ocean sector of the Southern Ocean Polish Polar Research 38 375-392

Mishra R K, Naik R K and Anilkumar N (2015) Adaptations of phytoplankton in the Indian Ocean sector of the Southern Ocean during austral summer of 1998-2014 Frontiers in 
Earth Science DOI 10.1007/s11707-015-0541-4

Naik R K, George J V, Soares M A, Devi A, Anilkumar N, Roy R, Bhaskar P V, Murukesh N and Achuthankutty C T (2015) Phytoplankton community structure at the juncture of the Agulhas Return Front and Subtropical Front in the Indian Ocean Sector of Southern Ocean: Bottom-up and top-down control Deep Sea Research Part II: Topical studies in Oceanography 118 233-239

Nair A, Mohan R, Crosta X, Manoj M C, Thamban M and Marieu V (2019) Southern Ocean sea ice and frontal changes during the Late Quaternary and their linkages to Asian summer monsoon Quaternary Science Reviews 213 93104

Nair A, Mohan R, Manoj M C and Thamban M (2015) GlacialInterglacial variability in diatom abundance and valve size: Implications for Southern Ocean paleoceanography Paleoceanography $\mathbf{3 0}$

Neethu C, K M, M R, K P, K, Saramma A and Hatha A (2012) Substrate Speciûcity of Cold Active Lipases of Psychrotrophic Bacteria from Kongsijord, and its Partial Characterization In: Advanced biotech 12 Samanthi Publications

Orme L C, Miettinen A, Divine D, Husum K, Pearce C, van Nieuwenhove N, Born A, Mohan R and Seidenkrantz MS (2018) Subpolar North Atlantic sea surface temperature since $6 \mathrm{ka} \mathrm{BP}$ : indications of anomalous ocean-atmosphere interactions at 4-2 ka BP Quaternary Science Review 194 128-142

PAGES 2k Consortium (2013) Continental-scale temperature variability during the past two millennia Nature Geoscience $6339-346$

Pant N C (1991) Metamorphic evolution of Humboldt- mountains, Dronning Maud Land, East Antarctica (Unpublished Ph.D. thesis submitted to M.L. Sukhadia University, Udaipur)

Pant N C, Jimenez-Espejo F J, Cook C P, Biswas P, Mckay R, Marchesi C, Ito M, Upadhyay D, Kuroda J, Shimizu K, Senda R, Flierdt Van De T, Takano Y, Suzuki K, Escutia C and Shrivastava P K (2018) Suspected meteorite fragments in marine sediments from East Antarctica Antarctic Science 30 307-321

Pant N C, Kundu A, Dsouza M J and Saikia A (2013) Petrology Indian Contributions to Antarctic Geology 277 of the Neoproterozoic granulites from Central Dronning Maud Land, East Antarctica- implications for southward extension of East African Orogen (EAO) Precambrian Research 227 389-408

Pant N C, Kundu A, Joshi S, Dey A, Bhandari A and Joshi A (2009) Chemical dating of monazite: testing of an analytical protocol against independently dated standards Indian Journal of Geosciences 63 311-31

Pant N C, Pandey M and Joshi S (2016) Polymetamorphic crust and a Neoproterozoic orogeny in the eastern Wilkes Land inferred from the marine sediments Abstracts XXXIV SCAR Open Science Conference Kualalumpur 115

Pant N C, Roy S, Ravikant V and Ravindra R (2017) Recent Contributions to the Antarctic Geology-An Indian Perspective Proceedings of the Indian National Science Academy 83 269-278

Phartiyal B, Sharma A and Bera S K (2011) Glacial lakes and geomorphological evolution of Schirmacher Oasis, East Antarctica, during Late Quaternary Quaternary International 235 128-136

Phartiyal B (2014) Holocene paleoclimatic variation in the Schirmacher Oasis, East Antarctica: A mineral magnetic approach Polar Science 8 357-369

Patil S M, Mohan R, Gazi S, Shetye S, Baumann K-H and Jafar S (2017) Biogeographical distribution of extant Coccolithophores in the Indian Sector of the Southern Ocean Marine Micropaleontology 137 16-30

Patil S M, Mohan R, Gazi S, Shetye S and Jafar S (2014b) Prymnesium neolepis (Prymnesiophyceae), a siliceous Haptophyte from the Southern Indian Ocean Micropaleontology $60475-481$

Patil S M, Mohan R, Gazi S, Shetye S and Jafar S (2016) Xenospheres and anomalous coccospheres from plankton samples of the Southern Indian Ocean Journal of Nannoplankton Research 36 1-4

Patil S M, Mohan R, Gazi S, Shetye S and Jafar S (2014a) Morphological variability of Emiliania huxleyi in the Indian Sector of the Southern Ocean during the austral summer of 2010 Marine Micropaleontology 107 44-58

Patil S M, Mohan R, Gazi S, Shetye S and Jafar S (2015) Petasaria heterolepis (Prymnesiaceae) from the Southern Indian Ocean Micropaleontology 61 171-176

Pillai H U K, Anilkumar N, Achuthankutty C T, Mendes C R, Sabu P, Jayalakshmi K V, Asha Devi C R, Dessai D, George J, Pavithran S, Hari Devi C K, Tripathy S C and Menon N $R$ (2018) Planktonic food web structure at SSTF and PF in the Indian sector of the Southern Ocean during austral summer of 2011 Polar Research 371495545

Prasanna K, Ghosh P, Bhattacharya S K, Mohan K and Anilkumar $\mathrm{N}$ (2016) Isotopic disequilibrium in Globigerina bulloides and carbon isotope response to productivity increase in Southern Ocean Scientific reports 621533

Prasanna K, Ghosh P and Anilkumar N (2015) Stable isotopic 
signature of Southern Ocean deep water $\mathrm{CO}_{2}$ ventilation Deep Sea Research II: Topical Studies in Oceanography 118 177-185

Rahaman W, Chatterjee S, Ejaz T and Thamban M (2019) Increased influence of ENSO on Antarctic temperature since the Industrial Era Scientific Reports 96006

Rahaman W, Thamban M and Laluraj C M (2016) Twentiethcentury sea ice variability in the Weddell Sea and its effects on moisture transport: Evidence from a coastal East Antarctic ice core record The Holocene 26 338-349

Rahul P, Prasanna K, Ghosh P, Anilkumar N and Yoshimura K (2018) Stable isotopes in water vapor and rainwater over Indian sector of Southern Ocean and estimation of fraction of recycled moisture Nature Scientific Reports 87552 , DOI:10.1038/s41598-018-25522-5

Ravikant V, Bhaskar Rao Y J and Gopalan K (2004) Schirmacher Oasis as an extension of the Neoproterozoic East African Orogen into Antarctica: New Sm-Ndisochron age constraints The Journal of Geology 12 607-616

Ravikant V, Laux J H and Pimentel M M (2007) Sm-Nd and U$\mathrm{Pb}$ isotopic constraints for crustal evolution during Late Neoproterozoic from rocks of the Schirmacher Oasis, East Antarctica: Geodynamic development coeval with East African Orogeny In: A K Cooper C R Raymond et al., Antarctica: A Keystone in a Changing world- Online proceedings of the 10th ISAES, USGS Open-File Report 2007-1047, Short Research Paper 007, 5pp. doi: 10.3133/ of 2007-1047.srp007

Raza M A, Saraswat R, Bhadra S R, Naik D K, Khare N, Govil P and Mazumder A (2018) Inverted sediments in the coastal Antarctic lake: Evidence of paleostorm Polar Science 18 213-219

Roy S K, Pant N C, Kundu A, Dharwadkar A, Kumar P K, Joshi S, Raghuram, Sadiq M and Pandey M (2017) Geological Studies in the Baalsrudfjelletnunatak and Wohlthat Mountains to establish the continuation of the East Antarctic Orogen (EAO) in the central Dronnn g Maud land, In: N C Pant and S Dasgupta (Eds) Crustal Evolution of India and Antarctica: The Supercontinent Connection Geological Society of London Special Publication 45737 60

Salam S, Lekshmi S, Silvester R, Krishnan K, Saramma A and Hatha A (2017) Effect of environmental factors on growth and enzyme production of cold adapted bacteria from water and sediment of Kongsfjord, Ny-Alesund, Arctic Journal of Environmental Biology 38579

Sabu P, Anilkumar N, George J V, Chacko R, Tripathy S C and Achuthankutty C T (2014) The influence of air-sea-ice interactions on an anomalous phytoplankton bloom in the Indian Ocean Sector of the Antarctic Zone of the Southern Ocean during the austral summer, 2011 Polar Science 8 $370-384$

Sabu P, George J V, Anilkumar N, Chacko R, Valsala V and Achuthankutty C T (2015) Observations of watermass modification by mesoscale eddies in the subtropical frontal region of the Indian ocean sector of southern ocean Deep Sea Research Part II: Topical studies in Oceanography 118 152-161

Scambos T A, Bohlander J A, Shuman C A and Skvarca P (2004) Glacier acceleration and thinning after ice shelf collapse in the Larsen B embayment, Antarctica Geophysical Research Letters 31 L18402

Shepherd A, Wingham D, Wallis D, Giles K, Laxon S and Sundal A V (2010) Recent loss of floating ice and the consequent sea level contribution Geophysical Research Letters 37 L13503

Shetye S S, Mohan R and Nair A (2014) Latitudinal shifts in the Polar Front in Indian sector of the Southern Ocean: evidences from silicoflagellate assemblage Geosciences Journal 18 241-246

Shivaji S (2017) Bacterial biodiversity, cold adaptation and biotechnological importance of bacteria occurring in Antarctica Proceedings of the Indian National Science Academy 83 327-352

Shukla S K, Crespin J and Crosta X (2016) Thalassiosira lentigenosa size variation and associated biogenic silica burial in the Southern Ocean over the last 42 kyrs Marine Micropaleontology 127 74-85

Shukla S K and Crosta X (2017) Fragilariopsis kerguelensis size variability from the Indian subtropical Southern Ocean over the last 42,000 years Antarctic Science 29 139-146

Shukla S K and Romero O E (2018) Glacial valve size variation of the Southern Ocean diatom Fragilariopsis kerguelensis preserved in the Benguela Upwelling System, southeastern Atlantic Palaeogeography, Palaeoclimatology, palaeoecology 499 112-122

Sinha R K, Krishnan K P, Kerkar S and Thresyamma D D (2017) Influence of glacial melt and Atlantic water on bacterioplankton community of Kongsfjorden, an Arctic fjord Ecological Indicators 82 143-151

Sivasankar P, Priyanka K, Rekadwad B, Sivakumar K, Thangaradjou T, Poongodi S, Manimurali R, Bhaskar P V and Anilkumar N (2018) Actinobacterial community structure in the Polar Frontal waters of the Southern Ocean of the Antarctica using Geographic Information System (GIS): A novel approach to study Ocean Microbiome Data 
in Brief 17 1307-1313

Srinivas T, Rao S N, Reddy P V V, Pratibha M, Sailaja B, Kavya B, Kishore K H, Begum Z, Singh S and Shivaji S (2009) Bacterial diversity and bioprospecting for cold-active lipases, amylases and proteases, from culturable bacteria of Kongsfjorden and Ny-Ålesund, Svalbard, Arctic Current microbiology 59 537-547

Soares M A, Bhaskar P V, Naik R K, Dessai D, George J, Tiwari $\mathrm{M}$ and Anilkumar N 2015. Latitudinal $\delta^{13} \mathrm{C}$ and $\delta^{15} \mathrm{~N}$ variations in particulate organic matter (POM) in surface waters from the Indian ocean sector of Southern Ocean and the Tropical Indian Ocean in 2012 Deep Sea Research Part II: Topical Studies in Oceanography 118 186-196

Stern R J (1994) Arc assembly and continental collision in the Neoproterozoic East African Orogen: Implications for the consolidation of Gondwanaland Annual Reviews of Earth and Planetary Sciences 22 319-351

Sun B, Greenbaum J, Blankenship D, Siegert M, Pant N, Guo J, Cui X, Wang B, Lindzey L, Li L, Arora D, Ng G and Richter T (2016) ICECAP-2 Aerogeophysical Observations of Princess Elizabeth Land, East Antarctica Abstract, XXXIV SCAR Open Science Conference Malaysia

Thamban M, Naik S S, Laluraj C M, Chaturvedi A and Ravindra $\mathrm{R}$ (2012) Antarctic climate variability during the past few centuries based on ice core records from Coastal droning Maud Land and its implications on the recent warming. In: Earth System Processes and Disaster Management. Edition: Society of Earth Scientists series, Sinha R, Ravindra R (eds). Springer, berlin, Heidelberg, 51-66

Thamban M, Laluraj C M and Mohan R (2016) Antarctic paleoclimate variability on Millennial, Centennial and Decadal time scales: Indian Initiatives during 2010-2015 Procedings of Indian National Science Academy 83 685694

Tripathy S C, Pavithran S, Sabu P, Naik R K, Noronha S B, Bhaskar P V and Anilkumar N (2014) Is primary productivity in the Indian Ocean sector of Southern Ocean affected by pigment packaging effect? Current Science 107 1019-1026
Tripathy S C, Pavithran S, Sabu P, Pillai H U K, Dessai D R G and Anilkumar N (2015) Deep chlorophyll maximum and primary productivity in Indian Ocean sector of the Southern Ocean: Case study in the Subtropical and Polar Front during austral summer 2011 Deep Sea Research Part II: Topical studies in Oceanography 118 240-249

Vekataramana V, Anilkumar N, Naik R K, Mishra R K and Sabu P (2019) Temperature and phytoplankton size class biomass drives the zooplankton food web dynamics in the Indian Ocean sector of the Southern Ocean Polar Biology 42 823-829

Venkatachalam S, Matcher G F, Lamont T, van den Berg M, Ansorge I J and Dorrington R A (2019) Influence of oceanographic variability on near-shore microbial communities of the sub-Antarctic Prince Edward Islands Limnology and Oceanography 64 258-271

Verma K, Bhattacharya S, Biswas P, Shrivastava P K, Pandey M, Pant N C, IODP Expedition 318 scientific party (2014) Clay mineralogy of the ocean sediments from the Wilkes Land margin, East Antarctica: Implications on the palaeoclimate, provenance and sediment dispersal pattern International Journal of Earth Science (Geol Rundsch) 103 2315-2326 (DOI) 10.1007/s00531-014-1043-4

Warrier A K, Mahesh B S and Mohan R (2017) Lake sediment studies in ice-free regions of East Antarctica - An Indian perspective Procedings of Indian National Science Academy 83 289-297

Warrier A K, Mahesh B S, Mohan R, Shankar R, Asthana R and Ravindra R (2014) Glacial-Interglacial climatic variations at the Schirmacher Oasis, East Antarctica: The first report from environmental magnetism Paleogeography, Paleoclimatology, palaeoecology 412 249-260

Warrier A K, Pednekar H, Mahesh B S, Mohan R and Gazi S (2015) Sediment grain size and surface textural observations of quartz grains in late quaternary lacustrine sediments from Schirmacher Oasis, East Antarctica: Paleoenvironmental significance Polar Science 10 89-100. 